\title{
The Impact of Perceived Social Support on the University 'Educators' Flourishing and the Moderating Effect of Challenge Appraisal
}

Quratulain Memon, Irma YazreenbintiMd Yusoff

To Link this Article: http://dx.doi.org/10.6007/IJARBSS/v12-i1/12138

DOI:10.6007/IJARBSS/v12-i1/12138

Received: 07 November 2021, Revised: 12 December 2021, Accepted: 04 January 2022

Published Online: 29 January 2022

In-Text Citation: (Memon \& Yusoff, 2022)

To Cite this Article: Memon, Q., \& Yusoff, I. Y. (2022). The Impact of Perceived Social Support on the University "Educators" Flourishing and the Moderating Effect of Challenge Appraisal. International Journal of Academic Research in Business and Social Sciences, 12(1), 2559-2580.

Copyright: (c) 2022 The Author(s)

Published by Human Resource Management Academic Research Society (www.hrmars.com)

This article is published under the Creative Commons Attribution (CC BY 4.0) license. Anyone may reproduce, distribute, translate and create derivative works of this article (for both commercial and non0-commercial purposes), subject to full attribution to the original publication and authors. The full terms of this license may be seen at: http://creativecommons.org/licences/by/4.0/legalcode

Vol. 12, No. 1, 2022, Pg. $2559-2580$

Full Terms \& Conditions of access and use can be found at http://hrmars.com/index.php/pages/detail/publication-ethics 


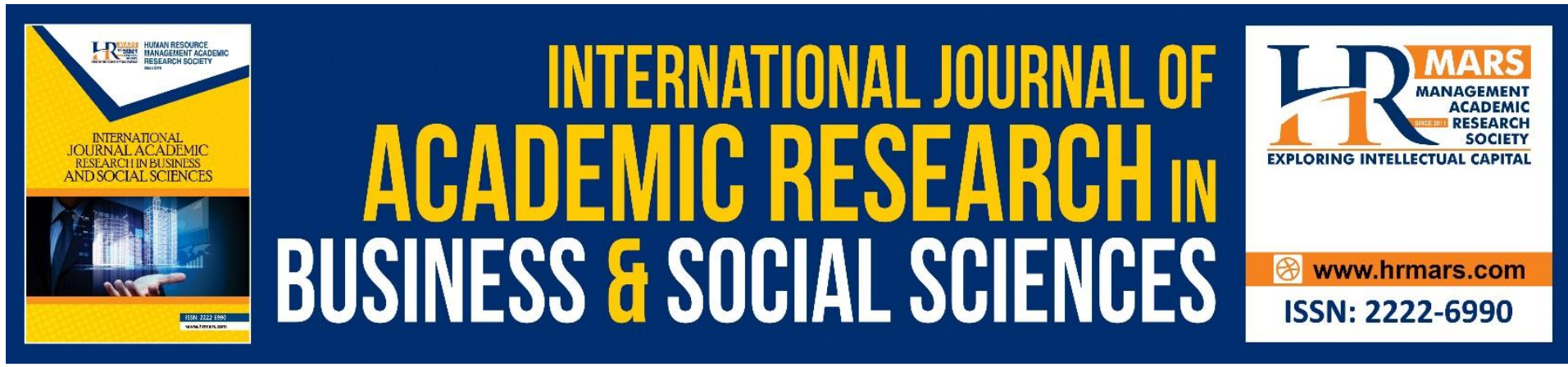

\title{
The Impact of Perceived Social Support on the University 'Educators' Flourishing and the Moderating Effect of Challenge Appraisal
}

\author{
Quratulain Memon \\ Ph.D. scholar, Faculty of Economics and Business, Universiti Malaysia Sarawak, Malaysia \\ Email: qmemon2013@gmail.com, quratulainmemon12@gmail.com (Corresponding Author)

\section{Dr Irma YazreenbintiMd Yusoff} \\ Senior Lecturer, Faculty of Economics and Business, Universiti Malaysia Sarawak, Malaysia \\ Email: myiyazreen@unimas.my
}

\begin{abstract}
This study provides insights into what makes teachers flourish in public sector universities of Sindh, Pakistan. Flourishing represents a balanced life where a person is happy with their status and is functioning effectively. The well-being of teachers has reportedly been lower than the general population (Education Support Partnership, 2019). Depressive symptoms were reported by $49 \%$ of 1189 academic staff members at 12 universities in Sindh, according to research on stress-related mental health problems in the Pakistani Scenario. Yet, research on evaluating teachers' mental health is lacking, notably among Pakistani university professors (Akram, 2019). Therefore, this study sheds light on the impact of perceived social support on educators' flourishing. Also, it discusses the boundary condition of challenge appraisals in this relationship. Statistical analysis was performed on data collected from 229 educators in Sindh, Pakistan's public sector universities. The result found a positive and statistically significant link between educators' perceptions of supervisors and co-worker support with educators' flourishing. However, challenge appraisal was found insignificant between exogenous and endogenous latent components. Overall, the study's findings suggest that perceived social support might help educators flourish at Sindh's public higher education institutions. The results' implications are discussed.
\end{abstract}

Keywords: Perceived Social Support, Supervisor Support, Co-worker Support, Educator's Flourishing, Challenge Appraisal, Higher Educational Institutions

\section{Introduction}

Mental health and well-being are crucial aspects of an organization's performance and success (Page et al., 2009). According to current arguments, employees face new problems as the working circumstances of globalized economies, new regulations, and technology change (Darus et al., 2016; Jiang et al., 2017). These worldwide upheavals show that 25 percent of the world's workforce, including educators, is unhappy with their employment. Organizations 
are therefore more concerned with the well-being of workers (Guest, 2017). One of the most stress-influenced sectors is higher education (Vera \& González-Ledesma, 2018).

Previous studies revealed that the well-being of educators is less than that of the general public (Education Support Partnership, 2019). More than one-third of educators experience stressful jobs (The Guardian, 2019). According to United Kingdom data on Education Support (2019), 72 percent of teachers characterized themselves as stressed, and 63 percent contemplated leaving today's post. In Northern Ireland, $74 \%$ of teachers report work stress, and $50 \%$ expressed a willingness to resign because of worries about health and well health (Education Support, 2019).

Recently, teachers' turnover has become a severe issue in Pakistan (Adil \& Khan, 2020). According to scholars, university educators in Pakistan are seriously suffering from occupational stress and burnout (Faisal \& Khair, 2019; Khan \& Anwar, 2019; Malik \& Björkqvist, 2018) leading to languishing and intentions to leave teaching profession (Rothmann \& Redelinghuys, 2020). Other scholars such as Khan, among 1,189 academic staff members at 12 institutions in Pakistan, mental health concerns revealed that $50 \%$ of academics had a significant fear, $49 \%$ had social problems, and $49 \%$ exhibited signs of depression. Scholars have stressed the elements that impact the psychological good of instructors, particularly among academicians in Pakistan (Akram, 2019). However, Pakistan's institutions are not adding the concept of well-being to their list of topmost priorities (Kamal, 2018). Therefore, policy frameworks need to be established to address the rising question of employee well-being before this impacts an increasing number of educators.

While literature examined the well-being and happiness of teachers, it focused mainly on the concept of deficiency and "unwell" instructors rather than on promoting a teacher's welfare. Luthans et al (2015) believe that concentrating on the positive is essential since organizations focus on the detrimental causes of combat or flight mode. When organizations focus on what has to be 'fixed,' they think closely rather than building to reduce the negative effect on their energy and resources. Positive psychology can be a new paradigm for enhancing the wellbeing of educational employees, according to Hoy and Tarter (2011) that lead to some fascinating and significant outcomes exist such aspositive self-esteem, satisfaction, affective organizational commitment, and intention to stay (Benevene et al., 2018; Lavy \& Bocker, 2018), but few and far between, emphasizing psychological well-being resources (Kun \& Gadanecz, 2019). Bakker and Demerouti (2016) suggested that instead of looking at what is wrong with employees, it was now possible to investigate under which conditions employees flourish at work.In short, flourishing is a complex structure consisting of good emotional wellbeing, positive psychological functioning, and positive social functioning that covers all aspects of mental health and is known as prosperity (Nelson et al., 2016). It promotes a stable and efficient organization (Boddy, 2014) and improves job performance (Wright \& Bonett, 2007).

Educators with job experience that enables them to be emotionally stable and operate psychologically and socially more successfully are more likely to fulfill institutional objectives in higher education such as Positive contacts with students, colleagues, and families and more remarkable academic outcomes (Kun \& Gadanecz, 2019). Well-being is linked with higher performance, as witnessed by a study conducted for the Pakistani telecom sector by AttaUllah et al (2018), which propels the need and viability of conducting more research on well-being. This could be why Pakistan fails to fulfill the objective of sustainable development to deliver quality education (Pakistan Economic Statistics Report, 2018). 
Empirical studies also revealed that the psychological flourishing of Pakistani educators is poor compared with the comparative education study instructors in the UK, the USA, Turkey, and Finland (Malik \& Björkqvist, 2018). It is acceptable to infer that educators' well-being is one of the financial burdens of society (Fontinha et al., 2019). Therefore the well-being of teachers is both a personal and societal burden. However, little study on teacher well-being and happiness has been carried out (Kun \& Gadanecz, 2019; Hoy \& Tarter, 2011; Benevene et al., 2018; Lavy \& Bocker, 2018). In particular, flourishing will be an effective tool to understand better employees' well-being (Hone et al., 2015; Czerw, 2017). Moreover, the evaluation and promotion of flourishing mental health are crucial for motivation, maintenance, performance, support, and retention (Marais-Opperman et al., 2021; Blustein, 2019; Kaufman, 2020).

A rising volume of literature highlights social support is an essential aspect of employee wellbeing. In general, the link between the person and the organization, according to Levinson (1965), is often established through relationships with representatives of the organization (e.g., leaders, supervisors). People with close social ties are better off and more prosperous (Diener et al., 2018).

Researchers have found that social support may be connected to work (i.e., supervisors, employees, and management) or not (i.e., the family, spouses, and partners) and may also take many forms in academic literature (Mihail \& Kloutsiniotis, 2016). The individual can seek social assistance in four areas: emotional support, instrumental support, information support, and assessment support, according to (Langford et al., 1997). Kossek et al (2011) defined general workplace assistance as supervisory or corporate support in the workplace, which might affect the well-being of employees.

The influence of social assistance on several aspects has been widely investigated. For example, on employee satisfaction and burnout, job burnout, recreation and well-being (Siedlecki et al., 2014; Kostak et al., 2019), and the performance of psychological security and service restoration, working hours, and psychological health and well-being (Siedlecki et al., 2014; Kostak et al., 2019; Memon et al., 2015). The many components of perceived social support can also predict various aspects of hedonic welfare (life satisfaction, positive and negative consequences) (Siedlecki et al., 2014). In addition, the connection between stress and well-being is considered to influence perceived social support (Poots and Cassidy, 2020). However, all these research generate ambiguous results, which suggest that social support and associated variables vary considerably in investigations. While research has shown various social support sources, the current study focuses on perceived support from supervisors and colleagues. The view of the people and the environment around them is impacted by the social support they perceive.

The degree to which a subordinate feels that their supervisor supports and respects them is described as perceived supervisor support. It also refers to the willingness of the supervisor to help the subordinate. Supervisors help colleagues who are an essential component of the social work environment and define the social environment. Whereas, Co-worker support means that a person feels that colleagues are helpful, is accessible where necessary and workrelated difficulties are solved (Babin \& Boles, 1996).

Several empirical research showed a beneficial link between supervisor and employee assistance and the development of employees (De Cordova et al., 2019; Imran et al., 2020). The creation of the aforementioned social support literature survey helps us comprehend perceived social support as an essential determinant of the employees' well-being. While the research related to happiness and well-being are mainly researched in Western nations, experts stressed that future studies should focus on variables that help grow in country- 
specific and cultural environments (Schotanus et al., 2016; Abid et al., 2018; Huppert et al., 2013). Moreover, Nielsen and Miraglia (2017) argued that higher education institutions need more individual interventions and better, tailor-made measures to get better performance (Kinman \& Johnson, 2019).

While previous research has found a positive relationship between job characteristics (e.g., perceived social support) and employee well-being, the degree of personal differences in assessing resources of employees plays a significant role in the relationship between perceived social support and its consequences. Individual differences in cognitive assessments, in particular, are likely to influence how employees perceive their job resources. As a result, the effects of these resources as challenges can result in positive outcomes. According to $\mathrm{Li}$ et al. (2020), resources can be challenging or hindering. Based on these arguments and recent empirical studies, this study aims to address O'Brien and Beehr (2019) claim that "appraisals may act as moderators, although little research has been done on that possibility" (Li et al., 2020; Li et al., 2017).

Second, we extend this person-environment fit theory-based research by examining how individual differences interact with the social environment to produce positive outcomes like educator flourishing. Finally, our study adds to the body of knowledge by investigating how job characteristics perceived as challenges predict educators' flourishing in Pakistani higher education institutions. It is widely accepted that external variables influence people's behaviors by shaping their attitudes (Glasman \& Albarracín, 2006). Thus, this study aims to determine whether 1 ) there is a link between Perceived Social Support (supervisor and coworker support) and educator's flourishing. 2) What role does challenge appraisal play in moderating the relationship between perceived social support and educator's flourishing? This study investigated challenge appraisal as a moderator supported by the personenvironment theory, which was not studied in the previous literature. As a result of these gaps, we focused our attention on developing countries like Pakistan

\section{Significance of the Study}

The study was motivated by the fact that Pakistan is developing ranks below the world average on most human development indicators. Developed countries like the USA (17.061\%), Japan (10.936\%), Canada (10.573\%), Scandinavian and Western European countries spend a large percentage of their GDP on healthcare. However, Pakistan spendsthe lowest among big countries of South Asia, i.e., 2.899\% of their GDPs to health Care, andbelowcriteria World Health Organizationcriteria (World Health Organization, 2019). Themedical costs and productivity losses accounted for $37 \%$ and $58.97 \%$ of the economic burden of mental health, respectively (Khan, 2016). As a developing country, Pakistan faces several challenges, and significant improvements are needed in different sectors; higher education is one of them.

Teacher turnover has recently become a significant issue in Pakistan (Adil \& Khan, 2020). In the context of Pakistan, university educators who suffer from occupational stress and burnout languish and have an intention to leave the institution (Faisal et al., 2019; Khan et al., 2019; Malik et al., 2018; Rothmann et al., 2020). This, in turn, will result in university educators' shortage, posing a barrier to achieving the higher education vision for 2025 that illustrate the expansion of existing institutions and the establishment of 300 new universities by 2025, an increase in faculty members, and the promotion of academic and research collaborations on an international scale (Pakistan Higher Education Commission. Vision, 2017). 
Therefore, this study is significant torespond to the scholars' calls to highlight the issue ofuniversity educators'well-being in Pakistani higher education institutions (Arshad, 2019; Khan et al., 2019; Malik et al., 2018). Likewise, this study is significant to address the goal ofthe Organization for Economic Co-operation and Development (OECD)toachieve teacher well-being and, in turn, preserve the profession's long-term sustainability (OECD. 2019b). Furthermore, this study will help Higher Education Commission achieve its 2025 vision and achieve the objective of having 51\% of the world's population prospering by 2051 (Seligman, 2011).

As a practical matter, this study is crucial in encouraging higher education institutions to prioritize faculty well-being and develop welfare policies to achieve beneficial outcomes for all stakeholders, including students, peers, supervisors, and the HElHigher educational institutes as a whole. As empirical research is scarce (Schotanus-Dijkstra et al., 2016; Abid et al., 2018), this study adds to the literature on the flourishing of non-Western states, making it possibly difficult to apply the findings to Asian countries such as Pakistan. Notably, most studies on flourishing have employed samples from Western countries (Abid et al., 2018; Colbert et al., 2016; Hefferon et al., 2017). Employees' well-being in the Pakistani context is fostered due to social support (high levels of supervisor and peer support), according to Ali and Imran (2020), and decreasing intentions of leaving. That way, this study is essential to highlight the significance of good working relationships with supervisors and colleagues as a predictor of the flourishing of educators in universities. In a collectivist culture, like Pakistan, people are deeply interdependent; however, seeking social assistance increases the risk of being judged by others or feeling inadequate and incompetent, lowering self-esteem. Therefore, this study suggests that the university leadership may formally initiate mentoring programs and workshops to achieve this goal because only a few high-profile, good-ranking universities in Pakistan support considerable social assistance to buffer the emotional demands of the job.

Additionally, organizations may help employees build amicable ties through casual meetings, get-togethers, celebration events, and functions from time to time. Employees might also be exposed to peer learning and group work concepts. That way, Organizational leaders contribute to creating supportive working to fulfill their socio-emotional needs and enhance their level of flourishing within higher educational institutions.

\section{Literature Review \& Hypothesis Development Employee Flourishing}

Employee Flourishing refers to an individual's mental health by integrating emotional states and personal functioning from private and public perspectives (Guo et al., 2021). People who flourish have a high degree of mental health, as shown by a pattern of feeling well (emotional well-being) and functioning well (psychological and social well-being) (Keyes, \& Annas, 2009). Flourishing has undergone many conceptualizations. Positive emotion $(P)$, engagement $(E)$, positive relations $(R)$, meaning $(M)$, and accomplishment are the five states linked with flourishing in Seligman's (2011) PERMA paradigm (A). Similarly, Huppert and colleagues (2013) identified their flourishing paradigm's positive feeling, involvement, purpose, and connections. Overall, the preceding models focused on flourishing, which refers to prospering outside work in daily life. Although each paradigm was necessary, they mainly focused on emotional and psychological factors while neglecting social issues. Keyes (2002) deviated from the widely held assumption that a person's lack of mental disease corresponds to mental wellness to address the previous gap. He created a thorough three-factor flourishing model 
based on Diener et al (1999) 's research. He concentrated on emotional well-being; Ryff (1989) differentiated between emotional and psychological well-being; and self-conducted research on social well-being.

As a consequence, Keyes (2010)referred to compositionof emotional well-being (EWB), psychological well-being (PWB), and social well-being (SWB) as criteria for flourishing individuals in public life. However, flourishing happens in work and organizational settings (Rothmann, 2013). Based on the Keyes (2002) research, Rothmann (2013) devised a flourishing model at work, understanding that flourishing is a multidimensional construct comprising EWB, PWB, and SWB. Said research on beneficial elements of mental health was ignored. While flourishing in the work environment generally shared 54 percent of the variation, he discovered that job-contextual variables were stronger predictors of flourishing. It also indicated more incredible organizational results than thriving overall. As a result, identifying the predictive characteristics of thriving workers is critical. When workers thrive, they feel they are essential organizational members, demonstrating positive views about the potential and variety of others. They feel comfort and support at work and significant and comprehensible organizational and social connections.

\section{Perceived Social Support and ' 'Educator's Flourishing}

Social support is broadly defined as "assistance accessible to a person via social connections to other individuals, organizations, and the broader society" (Lin et al., 1979, p. 109). In particular, perceived social support, in addition to supporting satisfaction, represents an individual's impression of the number of individuals accessible for assistance (Singstad et al., 2020). This implies that someone out there cares, values, and loves us, whether officials, direct supervisors, or informal, such as co-workers and family (Velando Soriano et al., 2020). Both official and informal, workplace assistance minimizes burnout, offers emotional and affective support, and improves general well-being (Soriano et al., 2020; Harandi et al., 2017). The more the perceived social support from colleagues and superiors, the stronger the social signals indicate that organizations care about their well-being. May et al (2004) discovered that rewarding and supportive interpersonal connections with colleagues and supervisors were indirectly linked to job engagement through the mediation function of psychological safety. Thus, we assume that the more supportive the organization's representatives, such as supervisors and co-workers, are perceived to be, the more the psychological relationship between the individual and the organization will be influenced by the exchange relationship, and thus the employee's attitudes and behaviors (ljaz \& Tarar, 2020)

Previous research found a link between perceived supervisor and co-worker support with positive outcomes such as employees'health and well-being (Valle, Andrews \&Kacmar, 2020). We argued here that supervisor and co-worker support in the form of employee value and care is considered organizational values, likely to foster positive attitudes and behaviors among employees (Rensburg et al., 2017). Prior research in this organizational setting has focused mainly on supervisory support and showed its positive consequences on work outcomes (Paterson et al., 2014). In comparison to supervisory support, the beneficial effect of co-workers is minimal (Sloan, 2012). Co-worker support is a significant resource at work that influences their quality of work-life and extends them socio-emotional support to function optimally. Co-workers promote collaboration, trust, and support as an information 
resource and are seen as an essential component of employee well-being via interpersonal connections (Sloan, 2012). However, few studies show the link between social support and ' 'Educator's Flourishing, scholars. Therefore Cobo-Rendón et al. (2020) suggested in their research that improving the perception of social support increases eudemonic well-being, which enhances their general well-being and contributes to their mental health. Therefore, the following hypothesis is proposed

\section{Hypothesis 1: Perceived supervisor support positively influence Educator's Flourishing Hypothesis 2:Perceived co-worker support positively influence Educator's Flourishing}

\section{ChallengeAppraisal as a Moderator between Perceived Social Support, Organizational Identification, and Educator's Flourishing}

The previous explanation is based on social exchange processes that demonstrated that social support and a surplus of particular work resources might result in positivecomes. However, this is not always the case since individuals can also evaluate their existing resources as (in) sufficient and unwelcoming (Beehr et al., 2010). It has something to do with the notion of cognitive evaluation. Cognitive appraisal evaluates a situation, which ultimately influences a problematic circumstance. As a result, Li et al (2020) propose that evaluation procedures for resources may exist in the same way they do for work needs.

Furthermore, the person-environment fit theory best describes it. It focuses on the connection between human traits and the environment, wherein the individual impacts their surroundings, but the environment also influences the individual (see earlier discussion of transactional models). The appropriateness of this fit between a person and their surroundings may impact motivation, behavior, and overall mental and physical health. We reason that the strength of connections between perceived social support and educator flourishing will vary with cognitive assessment, specifically, for employees who consider a specific job resource motivating and conducive to development and incentives (i.e., as a challenge, Podsakoff et al., 2007)-on the contrary, seeing workplace resources as a not challenging result in poor consequences. Earlier research on the moderators of the resourcesoutcome connection sheds light on the function of appraisals in moderating the perceived social support - well-being relationship. For example, Li et al (2017) found that reward appraisals affect the relationship between perceived reward for creativity and intrinsic motivation. When high challenge appraisal was high, the interaction between perceived reward for innovation and intrinsic motivation was positive (Hewett et al., 2018).

Colleague social support moderates the beneficial association between social support and techno-engagement.Support from colleagues contributed to their learning and improved their work positively affected techno engagement. On the contrary, the degree to which existing resources are (are) perceived adequate and under control is regarded as more or less complicated or impeding. Rukundo et al (2020) discovered that social support is often inadequate in their research. This lack of resources generated extra hindrance stress and was a strong predictor of psychophysiological symptoms. Hutchins (2019) discovered that a negative assessment of colleague social support, on the other hand, had no meaningful effect on technical involvement.

As a result, we predict that challenge evaluation moderates the connections between perceived social supports and flourishing. When challenge appraisal is high, the link between 
perceived social support and growing is more robust than when challenge appraisal is low. This model argues that challenge appraisal may influence how workers respond to resources (such as perceived social support), thus affecting the magnitude (and perhaps even the direction) of its connections with employee health. To summarise, the moderating function focuses on individual evaluations that influence how work resources are linked to educator'sflourishing. As a result, we want to know if instructors at higher education institutions see specific resources as demanding and how this affects their level of flourishing. The following hypothesis is suggested based on these considerations and recent empirical investigations (Li et al., 2020; 2017)

Hypothesis 3:Positive impact of perceived supervisor support on promoting educators'flourishing is more likely to occur if educators have a high challenge appraisal than if educators have a low challenge appraisal.

Hypothesis 4: Positive impact of perceived co-worker support on promoting educators' flourishing is more likely to occur if educators have a high challenge appraisal than if educators have a low challenge appraisal.

Given all that mentioned so far, the following research model is proposed.

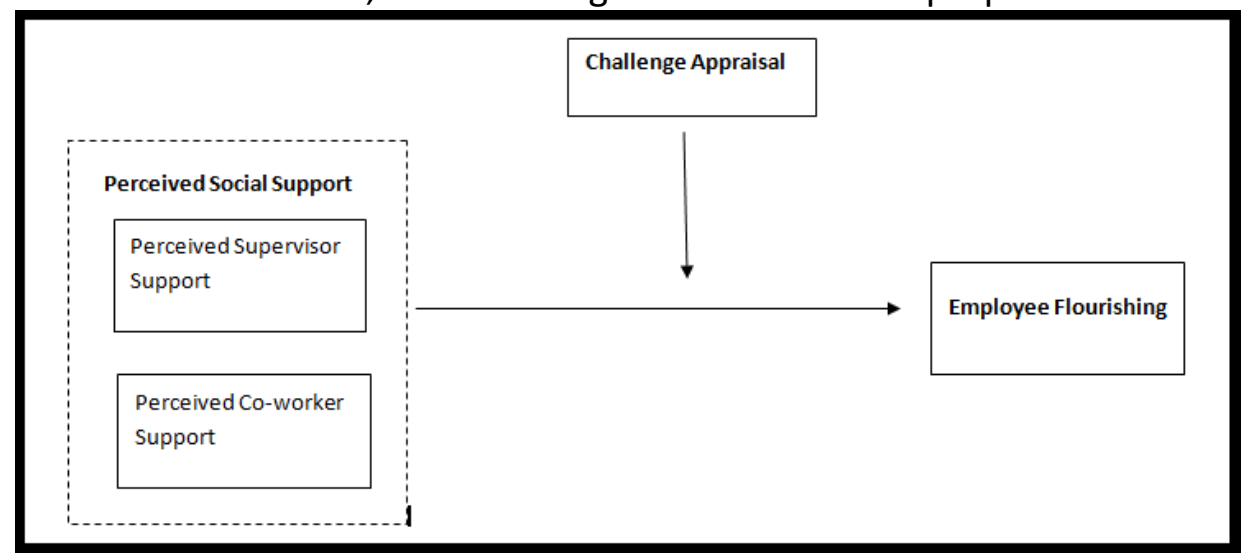

Figure 1: Conceptual Framework

\section{Research Method \\ Measures}

We have employed a seven-point Likert scale with anchors ranging from 1 = strongly disagree to $7=$ strongly agree in the current study. All measuring scales for this study were adapted from the existing measures. There were 19 items divided into three sub-sections: Perceived Social Support, challenge appraisal, and Educator's Flourishing. Karasek (1985) adopted the shorter version of the social scale to assess the educator'sperception of their co-worker and supervisor support. An 8-items social support scale assessed academicians' interpersonal coping resources where one person helps another and enhances that person's well-being. Educator's flourishing is measured by the Flourishing Scale developed by (Diener et al., 2009). It is a short 8-item scale to measure participants'self-perceived accomplishment in essential elements such as "relationship, self-esteem, purpose, and optimism. Challengeappraisals were based on Searle \&Auton's scale (2015) and adapted by (Li and Peeters, 2020). It was 
measured by eight items measuring appraisal of challenge (e.g., "will help me learn a lot") and hindrance (e.g.,"will restrict my capabilities").

\section{Sample}

This research adopted a cross-sectional approach using a questionnaire survey. Participants were contacted personally or via e-mail. Questionnaires were distributed in booklet form, along with a cover letter and a document stating that participation of this study was voluntary and that they are free to withdraw at any time without giving any reason. Since the study objective was to test the relationship among the variables, convenience sampling was used and should not produce any detrimental effects on the findings (Sternthal et al., 1994). To determine adequate sample size for the study, the G*Power 3.1 reveals that a sample size of 129 can estimate medium effect sizes at 95\% statistical levels (Faul et al., 2007). Thisstudy population was university lecturers from public sector higher educational institutions in Sindh, Pakistan. There are 25 public universities with around 7000 faculty members, as it was impossible to gather data from all public sector institutions spread throughout Pakistan. A total of 229 questionnaires were collected from the public sector university teachers of Sindh, Pakistan. A convenience sampling technique was used for data collection. The majority of the 229 questionnaire respondents (83.8 percent) were men. A master's degree was required for 95.6 percent of the participants. Regarding employment roles, 96 percent of participants were lecturers, 3.4 percent were assistant professors, and 1.6 percent were associate professors. Furthermore, 71.6 percent have less than one year of experience, 20.9 have fewer than five years of experience, 6.9 percent have 6 to ten years of work experience, and 0.43 percent have more than ten years of work experience. 63.7 percent were under 30, 24.8 percent were between 30 and 40, 6.9 percent were between 40 and 50, and 4.36 percent were between 50 and 60. PLS and SmartPLS version 3.0 software is used for data processing and analysis. The Partial Least Squares (PLS) technique is used in this research for hypothesis testing.

\section{Data Analysis and Results}

Structural equation modeling using Smart PLS 3.0 was used (Ringle et al., 2005). As suggested by renowned academics, the study was carried out in two stages: measurement model evaluation and structural model assessment (Hair et al., 2014). The proposed conceptual framework was evaluated for individual item reliability, convergent validity, and discriminant validity while assessing the measurement model (Hair et al., 2012). In terms of particular item dependability, the rule of thumb recommends that the external loadings of each item be at least 0.50 or higher. The total load of all objects is more than 0.5 .

Additionally, composite reliability ratings were calculated to confirm internal consistency dependability. The variables exceeded the standard criterion of 0.70 (Hair et al., 2011), demonstrating internal consistency dependability. Concurrently, the convergent validity of the constructs was evaluated by examining the extracted average variance. In this respect, Chin (1998) suggests a minimum threshold of 0.50. Table 1 demonstrates that all variables have surpassed the acceptable cut-off values, indicating the model's sufficient convergent validity (Chin, 1998). 
INTERNATIONAL JOURNAL OF ACADEMIC RESEARCH IN BUSINESS AND SOCIAL SCIENCES Vol. 12, No. 1, 2022, E-ISSN: 2222-6990 @ 2022 HRMARS

\begin{tabular}{|l|l|l|l|l|l|}
\hline Variables & Item & Loading & $\begin{array}{l}\text { Cronbach' } \\
\text { s Alpha }\end{array}$ & $\begin{array}{l}\text { Composite } \\
\text { Reliability }\end{array}$ & AVE \\
\hline Challenging Appraisal & CA1 & 0.809 & 0.907 & 0.935 & 0.783 \\
\hline & CA2 & 0.873 & & & \\
\hline & CA3 & 0.943 & & & \\
\hline Educator's Flourishing & CA4 & 0.909 & & & \\
\hline & EFL1 & 0.776 & 0.893 & 0.916 & 0.582 \\
\hline & EFL2 & 0.799 & & & \\
\hline & EFL3 & 0.693 & & & \\
\hline & EFL4 & 0.5 & & & \\
\hline & EFL5 & 0.774 & & & \\
\hline & EFL6 & 0.832 & & & \\
\hline & EFL7 & 0.831 & & & \\
\hline $\begin{array}{l}\text { Perceived Co-worker } \\
\text { Support }\end{array}$ & EFL8 & 0.841 & & & \\
\hline & PCS1 & 0.899 & 0.934 & 0.953 & \\
\hline & PCS2 & 0.933 & & & \\
\hline Support & PCS3 & 0.93 & & & \\
\hline & PCS4 & 0.893 & & & \\
\hline & PSS1 & 0.84 & 0.892 & 0.93 & \\
\hline & PSS2 & 0.868 & & & \\
\hline
\end{tabular}

Table 1. Loadings, Composite Reliability, and Average Variance Extract

Discriminate validity was evaluated in the following phase measurement model. Discriminate validity is defined as the extent to which a specific latent construct differs from other latent variables (Duarte and Raposo, 2010). The current study's discriminant validity was evaluated using AVE ratings, as Fornell and Larcker (1981) suggested. It was calculated by comparing the latent constructs'correlations to the square roots of the average variance retrieved (Fornell and Larcker, 1981). According to the authors, to achieve sufficient discriminant validity, the square root of the AVE should be greater than the correlations among the latent components. Table 2 shows that all square root values were more significant than the correlations, indicating acceptable discriminating validity.

\begin{tabular}{|l|l|l|l|l|}
\hline Variables & $\begin{array}{l}\text { Challenge } \\
\text { Appraisal }\end{array}$ & $\begin{array}{l}\text { Educator's } \\
\text { Flourishing }\end{array}$ & $\begin{array}{l}\text { Perceived Co- } \\
\text { worker } \\
\text { Support }\end{array}$ & $\begin{array}{l}\text { Perceived } \\
\text { Supervisor Support }\end{array}$ \\
\hline Challenge Appraisal & 0.885 & & & \\
\hline Educator's Flourishing & 0.494 & 0.763 & & \\
\hline Perceived Co-worker Support & 0.412 & 0.775 & 0.914 & \\
\hline Perceived Supervisor Support & 0.487 & 0.705 & 0.549 & 0.877 \\
\hline
\end{tabular}

Table 2: Discriminate validity of constructs 


\section{Structural Model Assessment}

Following a thorough analysis of the measurement model, the current research investigated the structural model to highlight the importance of the path coefficients Hair et al. (2012) and Hair et al. (, 2013; 2014). The direct and indirect impact significance tests are included in PLS hypothesis testing. The t-statistical test is used in the partial least squared (PLS) analysis model using the SmartPLS 3.0 software to perform the effect test. According to Table 3, the $R$ Square Educator's Flourishing (EFL) value of 0.719 indicates that perceived social support from supervisors and co-workers accounts for 71.9 percent of the Educator's Flourishing (EFL). In comparison, other factors account for the remaining 28.1 percent (not discussed in this research).

\begin{tabular}{|l|l|l|}
\hline Variable & R Square & R Square Adjusted \\
\hline Educator's Flourishing & 0.719 & 0.715 \\
\hline
\end{tabular}

Table 3: $R$ Square of Educator's Flourishing

While Table 4 displays the hypothesis testing between the research variables that have been mentioned are showed the T Statistics and P-Values.

\begin{tabular}{|l|l|l|l|l|l|l|l|}
\hline Hypothesis & Path & Beta & $\begin{array}{l}\text { Sample } \\
\text { Mean (M) }\end{array}$ & $\begin{array}{l}\text { Standard } \\
\text { Deviation } \\
\text { (STDEV) }\end{array}$ & $\begin{array}{l}\text { T Statistics } \\
(|O / S T D E V|)\end{array}$ & $\begin{array}{l}\text { P } \\
\text { Values }\end{array}$ & Decision \\
\hline $\mathrm{H} 1$ & $\begin{array}{l}\text { Perceived } \\
\text { Coworker } \\
\text { Support } \\
>\text { Educator's } \\
\text { Flourishing }\end{array}$ & 0.533196 & 0.535 & 0.054 & 9.874 & 0 & Supported \\
\hline $\mathrm{H} 2$ & $\begin{array}{l}\text { Perceived } \\
\text { Supervisor } \\
\text { Support } \\
>\text { Educator's } \\
\text { Flourishing }\end{array}$ & 0.36126 & 0.364 & 0.054 & 6.69 & 0 & Supported \\
\hline
\end{tabular}

Table 4: Structural Model Path Coefficients Assessment (Direct Effects)

Based on the statistical calculations summarized in Table 3 above, the direct effect between perceived supervisor support and co-worker support on Educator's Flourishing is significant,supporting hypotheses 1 and 2. However,the path modeling results found insignificant moderation of challenge appraisal on the relationship between perceived supervisor and co-worker support and Educator's Flourishing; hence, hypotheses 3 and 4 are rejected. Table 5, Fig.2, and Fig.3 provide further details in this regard.

\begin{tabular}{|l|l|l|l|l|l|l|l|}
\hline Hypothesis & Path & Beta & $\begin{array}{l}\text { Sample } \\
\text { Mean (M) }\end{array}$ & $\begin{array}{l}\text { Standard } \\
\text { Deviation } \\
\text { (STDEV) }\end{array}$ & $\begin{array}{l}\text { T Statistics } \\
(\mid \text { O/STDEV|) }\end{array}$ & $\begin{array}{l}\text { P } \\
\text { Values }\end{array}$ & Decision \\
\hline H3 & $\begin{array}{l}\text { PCSxCA } \\
\text { >Educator's } \\
\text { Flourishing }\end{array}$ & 0.07242 & -0.077 & 0.051 & 1.42 & 0.156 & $\begin{array}{l}\text { Not } \\
\text { Supported }\end{array}$ \\
\hline H4 & $\begin{array}{l}\text { PSSxCA } \\
\text { >Educator's } \\
\text { Flourishing }\end{array}$ & 0.004536 & 0.001 & 0.042 & 0.108 & 0.914 & $\begin{array}{l}\text { Not } \\
\text { Supported }\end{array}$ \\
\hline
\end{tabular}


Table 5: Structural Model Path Coefficients Assessment with moderation effect of Challenge Appraisal

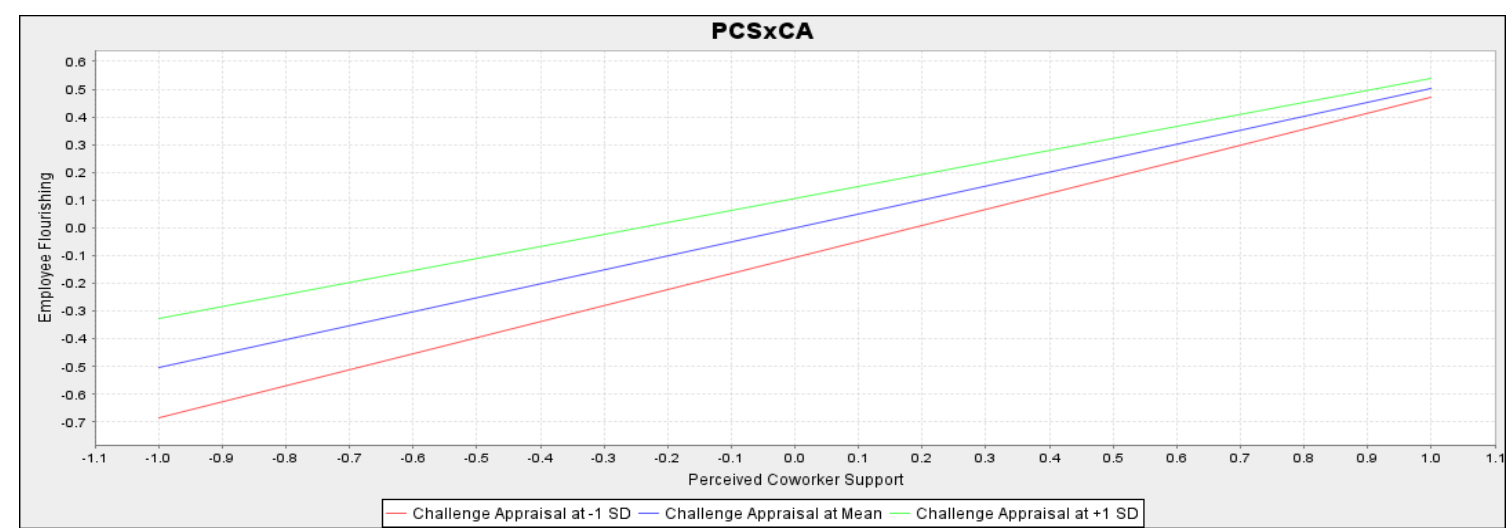

Figure 2. The interactions effect between perceived co-worker support and challenge appraisals on employee's flourishing

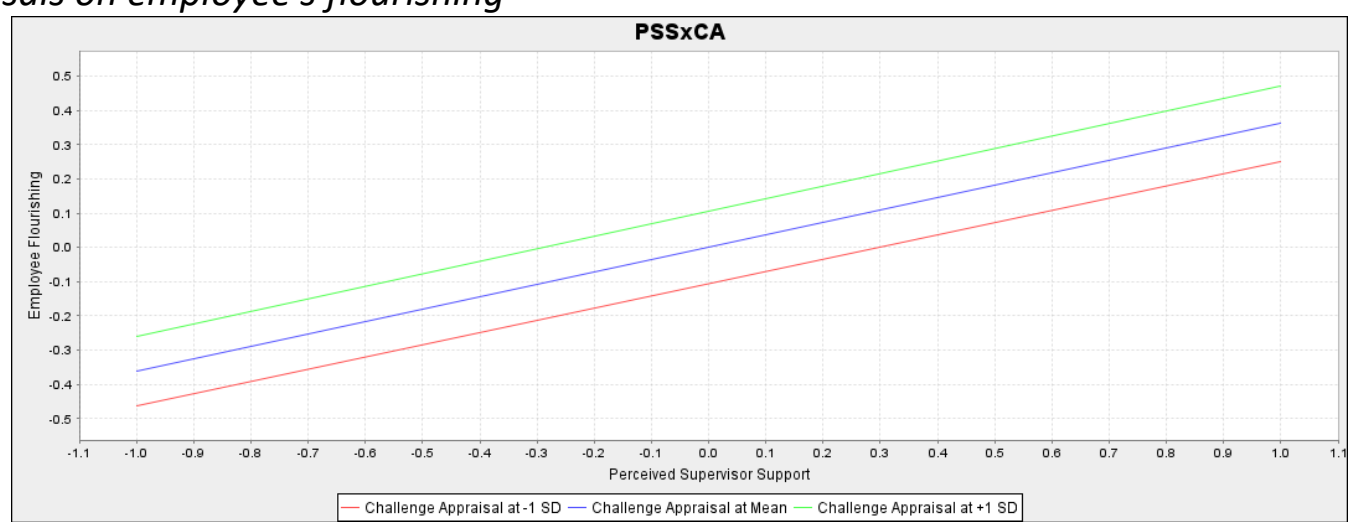

Figure 3. The interactions effect between perceived supervisor support and challenge appraisals on employee's flourishing

According to the statistical calculations presented in Table 3, the direct impact of perceived supervisor support and co-worker support on employee thriving is substantial, confirming hypotheses 1 and 2 . However, the path modeling findings revealed no substantial moderating of challenge appraisal on the connection between perceived supervisor and co-worker support and employee thriving. Thus hypotheses 3 and 4 are rejected. Table 4, Figures 1 and 2 Provides more information in this respect.

\section{Discussion}

The current study aimed to advance our understanding of the relationship between perceived social support and educators' flourishing and the moderating role of challenge appraisal between the flourishing relationships by integrating social exchange theory and personEnvironment Fit theory. Specifically, we focused on two sourcesof perceived social support (supervisor and co-worker support) and their links to educators flourishing. Secondly, we investigated the function of challenge assessment in moderating the link between supervisor and co-worker support withflourishing educators.

The study's first question was, "What is the connection between social support (supervisor and co-worker support) and educator flourishing?" As anticipated, supervisor and co-worker support predicted Educator's Flourishing. Educators Flourishing was predicted by supervisor and coworker support. These findings corroborate the social exchange hypothesis, which 
claims that people seek to reciprocate valued resource receipts to preserve high-quality exchange connections with other social entities (Blau, 1964). So, according to the social exchange approach, people flourish when they have excellent social exchange interactions with their supervisor and coworkers, thus accepting hypotheses 1 and 2: This finding is consistent with previous findings that stated a positive link between perceived supervisor support with flourishing (Jakeviit et al., 2021; Rensburg et al., 2017; Poortvliet et al., 2009) and co-worker support with flourishing (Truong, Nguyen \& Phan, 2021; Cordova et al., 2019; Kim et al, 2018) Hence, future studies may investigate additional supervisor and co-worker support aspects that encourage employees to reciprocate good workplace outcomes.

The study also addressed the following research question: What role does challenge appraisal impact perceived social support (supervisor and co-worker) and educator's flourishing? According to the results, the challenging appraisal did not affect the connection between supervisor and co-worker support with Educator's Flourishing (Hypothesis 3 and 4 are rejected). These results are consistent with the challenge-hindrance paradigm, which says that individuals who consider particular work demands difficult perform better (Cavanaugh et al., 2000). In this regard, co-workers who see co-workers as competitors do not ask for assistance and rely on their abilities. In other words, there is a mismatch between co-worker supplies and individual work values, resulting in poor work outcomes like flourishing. This assumption has never been tested in a prior study.

This research found that complex assessment of co-worker support acts as a filter for educators' views of their fit with the environment, resulting in poor job outcomes. Employees in collectivist nations like Pakistan may want less social assistance overall. Kim, Sherman and Taylor (2008), requesting social assistance is linked to the risk of getting a judgment from others, all of which are essential features of collectivist societies. These results also follow Hutchins (2019), who stated that social support from non-challenging colleagues had little effect on work-related well-being (i.e., techno engagement). According to the same research, supervisor social support challenge assessment has an impact on the connection between supervisor social and work-related well-being (i.e., techno engagement)

Overall, it seems that challenge appraisal has no impact on moderating the link between social support (supervisor and co-worker) and educators'flourishing. This means that there is only a direct relationship between two sources of support: supervisor and co-worker social support that directly predicts educators flourishing. Challenge appraisal is not identified to strengthen/weaken the relationship between perceived social support and flourishing. This argument is in line with the assumption of Li et al. (2020) that for job resources (for example, supervisor and co-worker), "assessment of a resource as a challenge should not have an impact on employee well-being (i.e., should not moderate the association between that resource and well-being).

This can be explained by the person-environment fit theory (Edwards, 1991), which states that if the resources of a person's environment do not match (fit) the person's standard, they will experience a misfit. This leads to decreased well-being and outcomes (van Vianen, 2018), such as flourishing. Therefore, we suggest that employers promote collaborative programs where supervisor and colleagues interaction is fostered to fulfill the socio-emotional needs of 
employees, giving workers the sense that the company fosters relatedness among supervisors and colleagues, resulting in cognitively rating the organization for their well-being.

\section{Implications}

The purpose and rationale of this study are to contribute to the scholarly literature in industrial and organizational psychology by filling a gap in the empirical data on the relationship between perceived social support and the flourishing of university educators. The study's findings indicated statistical significance to support the positive relationship between perceived social support, including increased supervisor and co-worker social support, and educators flourishing in the higher education sector. The intervention by challenge appraisal, on the other hand, was not found to strengthen/weaken the relationship between perceived social support and flourishing. Even though supportive colleagues at work enable educators to be happy and satisfied while achieving university output, they are not viewed as a source of personal development in this context. The significant findings have improved organizational researchers' theoretical knowledge by demonstrating that social resources such as supervisor and colleague support are essential and deemed vital for educators in higher educational institutions across all occupational contexts. Similarly, the results assert that social exchange theory stresses the reciprocity of resources between employers and workers in influencing behavior and outcomes (Blau, 1968). The research replied by confirming the significance of perceived supervisor and co-worker support in fostering and enhancing employee functioning, such as flourishing.

Furthermore, the researchers discovered that, as a moderating variable, challenge assessment did not affect the connection between perceived social support (supervisor and colleague) and educator's flourishing.We assume that P-E fit theories (person-environment fit) are essential for understanding the continuous reciprocal process by which people shape their behavior underlying a fit between the environmental supplies and individual values (Rounds et al., 1990; Edwards, 1996). In line with the Person-Environment Fit theories, this study contributes toa lack of fit between perceived social support and individuals' work values, thereby notpredictingthelevel of flourishing among educators.

Given that the supervisor and Co-workers are critical elements in organizational settings who may fulfill (or not fulfill) the values of the workers, the impression of supervisor support will filter the impact of value fulfillment on employee outcomes. A good work outcome is more probable when the experience of supervisor support gives the employee what the person wants. But when there is a mismatch between former and latter, adverse effects may likely occur, such as a low level of flourishing. In a similar vein, employees' work value also relates to their desire for pleasant relations with their colleagues and an enjoyable work environment. When workers are not provided with co-worker-worker support what they desire rather than what they value, it creates unpleasant emotions in the individual and misfits between the supplies and individual values at work, reducing flourishing. To the best of our knowledge, no study has explicitly investigated the underlying premise in challenging assessment regarding how supervisor support satisfies the employee's socio-emotional needs and leads to enhancing/reducing the level of flourishing.

Thereby integrating social exchange and Person-Environment fit theory, educators'flourishing research was more predictive power, application potential, and adaptability. The 
combination of perceived supervisor support, co-worker-worker support, and challenge appraisal in Pakistan's higher education industry has made the framework more theoretically robust and empirically scalable by addressing significant gaps, especially in the developing nation of Pakistan. The research results have added to the body of supervisor and co-worker support knowledge. In practice, the study's findings concentrated on the service industry. In terms of higher education institutions, the current study provides a framework for evaluating the impact of various resources such as perceived supervisor support, co-worker-worker support, and challenge appraisal in improving Educator's Flourishing across different job ranks.

Furthermore, the current research offers an empirically validated paradigm for 'employer welfare top management, defining responsibilities and employment opportunities for cultivating employee happiness. Alternatively, it has been shown that supportive supervisor and co-worker support in the workplace causes workers to flourish emotionally, mentally, and socially, resulting in more incredible employee performance at work. As a result, senior management must adopt and promote such tools to enhance Educator's Flourishing. Furthermore, it will provide insights to both the Industrial/Organizational Psychologists and the HR Departments of organizations in designing interventions and launching programs and initiatives to improve university educators' flourishing andinstitutional health. Consequently, these would lead to reduced medical costs and lowered absenteeism as well as increased employee engagement levels and performance (Beichl, 2015)

\section{Limitations and Future Research Directions}

Despite obtaining numerous interesting findings, the current study has certain limitations. First, the study's conclusions were exclusively applicable to the higher education sector. Furthermore, because this study only included faculty members from public sector higher education institutions in Sindh, Pakistan, its findings may be limited in their generalizability. Furthermore, additional study in another occupational context is encouraged. Second, the current study used a survey approach with a cross-sectional design. Notably, future research may look at the study's longitudinal approach. Third, another weakness of the current study was the self-reporting survey. A self-reporting survey can exaggerate the relationship between an external component and an endogenous construct. As a result, future academics may use alternate methodologies, such as qualitative or focus group methods. Fourth, it isn't easy to generalize the current study's conclusions because the data was obtained from a single province, Sindh, in Pakistan. Consequently, it may be suitable to include educators from other provinces functioning in Pakistan and the private sector in the study sample to generalize the findings.

\section{Conclusion}

Our studies advance perceived social support research by proposing and testing a moderated model of perceived social support using university educators in Pakistani Higher educational institutions. Our findings add important value to the literature by delineating boundary conditions that showed no effect on the relationship between perceived social support and educators' flourishing. Although we focused on one form of appraisal, i.e., challenge, future investigations into other forms of appraisal, i.e.,hindrance as additional moderators could complement the findings of the current research and enrich the knowledge of boundary conditions that affect perceived social support 


\section{Acknowledgment}

The authors wish to thank the Faculty of Economics and Business, University Malaysia Sarawak, Malaysiaby funding this research.

\section{References}

Abid, G., ljaz, S., Butt, T., Farooqi, S., \& Rehmat, M. (2018). Impact of perceived internal respect on flourishing: A sequential mediation of organizational identification and energy. Cogent Business \& Management, 5(1), 1507276.

Adil, M. S., \& Khan, U. (2020). Antecedents of Cognitive Job Engagement and its Effect on Teacher Performance: Moderating Roles of Occupational Stress and Mentoring. DOI: 10.20547/jess0812008103

Akram, M. (2019). Psychological Well-being of University Teachers in Pakistan. Journal of Education and Educational Development, 6(2), 235-253.

Arshad, M. (2019). Professional life stressors among teaching faculty at tertiary level. UMT Education Review, 2(2), 27-46.

Ali, S., \& Imran, R. (2020). An Empirical Study on Teachers' well-being in Higher Education Institutions: The Case of Pakistan. Journal of Social Sciences \& Humanities (19947046), 28(2).

Arshad, M. (2019). Professional life stressors among teaching faculty at tertiary level. UMT Education Review, 2(2), 27-46.

Arthur Jr, W., Bell, S. T., Villado, A. J., \& Doverspike, D. (2006). The use of person-organization fit in employment decision making: an assessment of its criterion-related validity. Journal of applied psychology, 91(4), 786.

Ali, S., \& Imran, R. (2020). An Empirical Study on Teachers' wellbeing in Higher Education Institutions: The Case of Pakistan. Journal of Social Sciences \& Humanities (19947046), 28(2).

Bakker, A. B., \&Demerouti, E. (2016). Job Demands-Resources Theory: Taking Stock and Looking Forward

Beehr, T. A., Bowling, N. A., \& Bennett, M. M. (2010). Occupational stress and failures of social support: when helping hurts. Journal of occupational health psychology, 15(1), 45.

Benevene, P., Ittan, M. M., \&Cortini, M. (2018). Self-esteem and happiness as predictors of school teachers' health: the mediating role of job satisfaction. Frontiers in psychology, 9, 933.

Blau, P. M. (1968). Social exchange. International encyclopedia of the social sciences, 7, 452457.

Blustein, D. L. (2019). The importance of work in an age of uncertainty: The eroding work experience in America. Oxford University Press. Boddy, C. R. (2014). Corporate psychopaths, conflict, employee affective well-being and counterproductive work behaviour. Journal of business ethics, 121(1), 107-121.

Cavanaugh, M. A., Boswell, W. R., Roehling, M. V., \& Boudreau, J. W. (2000). An empirical examination of self-reported work stress among US managers. Journal of applied psychology, 85(1), 65.

Chin, W. W. (1998). Commentary: Issues and opinion on structural equation modeling.

Cobo-Rendón, R., Vega-Valenzuela, A., \&García-Álvarez, D. (2020). Institutional considerations on Mental Health in college students during the Covid-19 pandemic. SienciAmerica , 
Colbert, A. E., Bono, J. E., \&Purvanova, R. K. (2016). Flourishing via workplace relationships: Moving beyond instrumental support. Academy of Management Journal, 59(4), 11991223.

Czerw, A. (2019). Diagnosing well-being in work context-eudemonic well-being in the workplace questionnaire. Current Psychology, 38(2), 331-346.

Darus, A., Azizan, F. L., \& Ahmad, F. (2016). Work stress, pay satisfaction, psychological empowerment and organisational commitment among academic staff. International Journal of Management Studies, 23(1), 51-72.

https://doi.org/10.32890/ijms.23.1.2016.10466

De Cordova, F., Berlanda, S., Pedrazza, M., \&Fraizzoli, M. (2019). Violence at school and the well-being of teachers. The importance of positive relationships. Frontiers in psychology, 10, 1807.

Deelstra, J. T., Peeters, M. C., Schaufeli, W. B., Stroebe, W., Zijlstra, F. R., \& van Doornen, L. P. (2003). Receiving instrumental support at work: when help is not welcome. Journal of applied psychology, 88(2), 324.

Diener, E., Lucas, R. E., Oishi, S., Hall, N., \&Donnellan, M. B. (2018). Advances and open questions in the science of subjective well-being. Collabra: Psychology, 4(1).

Duarte, P. A. O., \&Raposo, M. L. B. (2010). A PLS model to study brand preference: An application to the mobile phone market. In Handbook of partial least squares (pp. 449485). Springer, Berlin, Heidelberg.

Education Support Partnership. (2019). Health survey 2017: The mental health and well-being of education professionals in the UK. YouGov. Retrieved from https://www.educationsupport.org. uk/sites/default/files/education_staff_health_survey_2017.pdf.

Edwards, J. R. (1996). An examination of competing versions of the person-environment fit approach to stress. Academy of management journal, 39(2), 292-339.

Faisal, F., Noor, N., \&Khair, A. (2019). Causes and Consequences of Workplace Stress among Pakistan University Teachers. Bulletin of Education and Research, 41(3), 45-60.

Fontinha, R., Easton, S., \& Van Laar, D. (2019). Overtime and quality of working life in academics and nonacademics: The role of perceived work-life balance. International Journal of Stress Management, 26(2), 173.

Fornell, C., \&Larcker, D. F. (1981). Structural equation models with unobservable variables and measurement error: Algebra and statistics.

Glasman, L. R., \&Albarracín, D. (2006). Forming attitudes that predict future behavior: a metaanalysis of the attitude-behavior relation. Psychological bulletin, 132(5), 778.

Greguras, G. J., \& Diefendorff, J. M. (2009). Different fits satisfy different needs: linking person-environment fit to employee commitment and performance using selfdetermination theory. Journal of applied psychology, 94(2), 465.

Guest, D. E. (2017). Human resource management and employee well-being: Towards a new analytic framework. Human resource management journal, 27(1), 22-38.

Guo, S., Cheung, C. K. J., Hu, J., \& Ning, X. (2021). The moderation effect of identity exploration and basic psychological needs satisfaction on flourishing of Chinese rural children. Psicologia: Reflexão e Crítica, 34.

Hair Jr, J. F., Sarstedt, M., Hopkins, L., \&Kuppelwieser, V. G. (2014). Partial least squares structural equation modeling (PLS-SEM): An emerging tool in business research. European business review. 
Hair, J. F., Ringle, C. M., \&Sarstedt, M. (2011). PLS-SEM: Indeed a silver bullet. Journal of Marketing theory and Practice, 19(2), 139-152.

Hefferon, K., Ashfield, A., Waters, L., \&Synard, J. (2017). Understanding optimal human functioning-The 'call for qual'in exploring human flourishing and well-being. The Journal of Positive Psychology, 12(3), 211-219.

Hewett, R., Shantz, A., Mundy, J., \&Alfes, K. (2018). Attribution theories in human resource management research: A review and research agenda. The International Journal of Human Resource Management, 29(1), 87-126.

Higher Education Statistics Agency. (HSEA). (2020). Higher education staff statistics: UK, 2018/19. Retrieved from https://www.hesa.ac.uk/news/23-01-2020/sb256-highereducation-staff-statistics\#: :text=In\%20201 8\%2F19\%2C\%2098\%2C600\%2C,was\%20100\%2C120\%2C\%20or\%2047\%25

Hone, L. C., Jarden, A., Duncan, S., \& Schofield, G. M. (2015). Flourishing in New Zealand workers: Associations with lifestyle behaviors, physical health, psychosocial, and workrelated indicators. Journal of Occupational and Environmental Medicine, 57(9), 973983.

Hoy, W. K., \& Tarter, C. J. (2011). Positive psychology and educational administration: An optimistic research agenda. Educational Administration Quarterly, 47(3), 427-445.

Huppert, F. A., \& So, T. T. (2013). Flourishing across Europe: Application of a new conceptual framework for defining well-being. Social indicators research, 110(3), 837-861.

Hutchins, J. S. C. (2019). Technological fun in the workplace: The Role of Resources and Appraisal on Technostrain and Techno Engagement (Master's thesis).

Hutchins, J. S. C. (2019). Technological fun in the workplace: The Role of Resources and Appraisal on Technostrain and Techno Engagement (Master's thesis).

Ijaz, M. M., \&Tarar, A. H. (2020). Work Autonomy, Organizational Climate and Employee Engagement. Pakistan Journal of Social and Clinical Psychology, 18(1), 43-55

Imran, M. Y., Elahi, N. S., Abid, G., Ashfaq, F., \&llyas, S. (2020). Impact of perceived organizational support on work engagement: Mediating mechanism of thriving and flourishing. Journal of Open Innovation: Technology, Market, and Complexity, 6(3), 82.

Janse van Rensburg, C., Rothmann, S. S., \& Diedericks, E. (2017). Person-environment fit, flourishing and intention to leave in universities of technology in South Africa. SA Journal of Industrial Psychology, 43(1), 1-10.

Jaškevičiūtè, V., Stankevičienè, A., Diskienè, D., \&Savickè, J. (2021). The relationship between employee well-being and organizational trust in the context of sustainable human resource management. Problems and perspectives in management, 19(2), 118-131.

Kamal, D. (2018). Mental health at the workplace. Daily Times

Kaufman, S. B. (2020). Transcend: The new science of self-actualization. New York, NY: Penguin.

Keyes, C. L. (2002). The mental health continuum: From languishing to flourishing in life. Journal of health and social behavior, 207-222.

Keyes, C. L., \& Annas, J. (2009). Feeling good and functioning well: Distinctive concepts in ancient philosophy and contemporary science. The journal of positive psychology, 4(3), 197-201.

Keyes, C. L., \& Haidt, J. (2010). Flourishing. Corsini encyclopedia of psychology.

Khan, A., Yusoff, R. B. M., \& Isa, K. B. (2016). Examining Linkages between Psychological Health Problems, Socio-Demographic Characteristics and Workplace Stressors in Pakistan's Academia. International Education Studies, 9(6), 108-119. 
Khan, A., Din, S. U., \& Anwar, M. (2019). Sources and adverse effects of burnout among academic staff: A systematic review. City University Research Journal, 9(2), 350-363

Khan, M. M. (2016). Economic burden of mental illnesses in Pakistan. Journal of Mental Health Policy and Economics, 19(3), 155

Khan, F., Rasli, A. M., Yasir, M., \& Khan, Q. (2019). Interaction effect of social support: the effect of workload on job burnout among universities academicians: case of Pakistan. Int Transact J Eng Manage ApplSciTechnol, 10(13), $10 \mathrm{A3}$.

Kim, D., Moon, C. W., \& Shin, J. (2018). Linkages between empowering leadership and subjective well-being and work performance via perceived organizational and coworker support. Leadership \& Organization Development Journal.

Kim, H. S., Sherman, D. K., \& Taylor, S. E. (2008). Culture and social support. American psychologist, 63(6), 518.

Kinman, G., \& Johnson, S. (2019). Special section on well-being in academic employees. International Journal of Stress Management, 26(2), 159.

Kossek, E. E., Pichler, S., Bodner, T., \& Hammer, L. B. (2011). Workplace social support and work-family conflict: A meta-analysis clarifying the influence of general and workfamily-specific supervisor and organizational support. Personnel psychology, 64(2), 289313.

Kostak, M. A., Dindar, I., \& Dinçkol, R. Z. (2019). Loneliness, depression, social support levels, and other factors involving the internet use of high school students in Turkey. International Journal of Mental Health and Addiction, 17(6), 1521-1534.

Kun, A., \& Gadanecz, P. (2019). Workplace happiness, well-being and their relationship with psychological capital: A study of Hungarian Teachers. Current Psychology, 1-15.

Kuriakose, V., \& Jose, H. (2020). Examining the Mechanisms Linking Work-Related Conflicts and Employee Well-Being: A Mediation Model. American Business Review, 23(2), 4.

Langford, C. P. H., Bowsher, J., Maloney, J. P., \& Lillis, P. P. (1997). Social support: a conceptual analysis. Journal of advanced nursing, 25(1), 95-100.

Lavy, S., \&Bocker, S. (2018). A path to teacher happiness? A sense of meaning affects teacherstudent relationships, which affect job satisfaction. Journal of Happiness Studies, 19(5), 1485-1503.

Levinson, H. (1965). Reciprocation: the relationship between man and organization. Administrative Science Quarterly 9 (March), 370

Li, F., Deng, H., Leung, K., \& Zhao, Y. (2017). Is perceived creativity-reward contingency good for creativity? The role of challenge and threat appraisals. Human Resource Management, 56(4), 693-709.

Li, P., Peeters, M. C., Taris, T. W., \& Zhang, Y. (2020). Challenges or Hindrances? Implications of Work Characteristics Appraisals for Employees' Well-Being.

Lin, N., Ensel, W. M., Simeone, R. S., \&Kuo, W. (1979). Social support, stressful life events, and illness: A model and an empirical test. Journal of Health and Social Behavior, 108-119.

Luthans, F., Youssef, C. M., \&Avolio, B. J. (2015). Psychological capital and beyond. Oxford University Press, USA.

Malik, N. A., \&Björkqvist, K. (2018). Occupational stress and mental and musculoskeletal health among university teachers. Eurasian Journal of Medical Investigation, 2(3), 139147.

Marais-Opperman, V., Rothmann, S. I., \& van Eeden, C. (2021). Stress, flourishing and intention to leave of teachers: Does coping type matter?. SA Journal of Industrial Psychology, 47(1), 1-11. 
Memon, M. A., Salleh, R., \& Baharom, M. N. R. (2015). Linking Person-Job Fit, Personorganization fit, employee engagement and turnover intention: A three-step conceptual model. Asian Social Science, 11(2), 313.

Mihail, D. M., \&Kloutsiniotis, P. V. (2016). The effects of high-performance work systems on hospital employees' work-related well-being: Evidence from Greece. European Management Journal, 34(4), 424-438.

Nelson, S. K., Layous, K., Cole, S. W., \& Lyubomirsky, S. (2016). Do unto others or treat yourself? The effects of prosocial and self-focused behavior on psychological flourishing. Emotion, 16(6), 850.

O'Brien, K. E., \& Beehr, T. A. (2019). So far, so good: Up to now, the challenge-hindrance framework describes a practical and accurate distinction. Journal of Organizational Behavior, 40(8), 962-972.

OECD. (2019b). TALIS 2018 Technical Report: Preliminary version. Paris: OECD. Accessed $27 / 08 / 2019$

Page, K. M., \& Vella-Brodrick, D. A. (2009). The 'what', 'why'and'how'of employee well-being: A new model. Social indicators research, 90(3), 441-458.

Pakistan Higher Education Commission. Vision 2025. JUNE (2017). Contact: Joseph Taylor. Policy Manager, Asia

Podsakoff, N. P., LePine, J. A., \& LePine, M. A. (2007). Differential challenge stressor-hindrance stressor relationships with job attitudes, turnover intentions, turnover, and withdrawal behavior: a meta-analysis. Journal of applied psychology, 92(2), 438.

Poots, A., \& Cassidy, T. (2020). Academic expectation, self-compassion, psychological capital, social support and student well-being. International Journal of Educational Research, 99, 101506.

Ringle, C. M. (2005). SmartPLS 2.0 (M3). http://www. smartpls. de.

Rothmann, S., \& Redelinghuys, K. (2020). Exploring the prevalence of workplace flourishing amongst teachers over time. SA Journal of Industrial Psychology, 46(1), 1-7.

Rothmann, S. (2013). From happiness to flourishing at work: A Southern African perspective. In Well-being research in South Africa (pp. 123-151). Springer, Dordrecht.

Rothmann, S., \& Welsh, C. (2013). Employee engagement: The role of psychological conditions. Management Dynamics: Journal of the Southern African Institute for Management Scientists, 22(1), 14-25.

Rounds, J. B., \& Tracey, T. J. (1990). From trait-and-factor to person-environment fit counseling: Theory and process.

Rukundo, C., Nguema, J. N. B., Atamba, C., Halima, M. H., \&Neku, A. (2020). Thriving from Challenges Stress: The Interactive Effect of Role Conflict, Time Pressure, and Negative Affect on Chinese Employees' Work Engagement. International Journal of Human Resource Studies, 10(4).

Ryff, C. D. (1989). Happiness is everything, or is it? Explorations on the meaning of psychological well-being. Journal of personality and social psychology, 57(6), 1069.

Schotanus-Dijkstra, M., Pieterse, M. E., Drossaert, C. H., Westerhof, G. J., De Graaf, R., Ten Have, M., ... \&Bohlmeijer, E. T. (2016). What factors are associated with flourishing? Results from a large representative national sample. Journal of happiness studies, 17(4), 1351-1370.

Siedlecki, K. L., Salthouse, T. A., Oishi, S., \&Jeswani, S. (2014). The relationship between social support and subjective well-being across age. Social indicators research, 117(2), 561576. 
Singstad, M. T., Wallander, J. L., Lydersen, S., Wichstrøm, L., \& Kayed, N. S. (2020). Perceived social support among adolescents in Residential Youth Care. Child \& Family social work, 25(2), 384-393.

Sloan, M. M. (2012). Unfair treatment in the workplace and worker well-being: The role of coworker support in a service work environment. Work and Occupations, 39(1), 3-34.

The Guardian. (2019). Austerity created this mental-health crisis. Brexit has sent it into overdrive.

Retrieved from:https://www.theguardian.com/commentisfree/2019/mar/14/\%20austeritymental-health-brexit

Valle, M., Andrews, M. C., \&Kacmar, K. M. (2020). Situational antecedents to organizational identification and the role of supervisor support. Organization Management Journal.

Velando-Soriano, A., Ortega-Campos, E., Gómez-Urquiza, J. L., Ramírez-Baena, L., De La Fuente, E. I., \&Cañadas-De La Fuente, G. A. (2020). Impact of social support in preventing burnout syndrome in nurses: A systematic review. Japan Journal of Nursing Science, 17(1), e12269.

Vera, H., \& González-Ledesma, M. A. (2018). Calidad y evaluación: matrimoniodelcielo y el infierno. Perfileseducativos, 40(SPE), 53-97.

Wright, T. A., \&Bonett, D. G. (2007). Job satisfaction and psychological well-being as nonadditive predictors of workplace turnover. Journal of Management, 33(2), 141-160. 